\title{
Comparison of the carbon sequestration potential of young Tectona grandis L. f. (Teak) and Dendrocalamus strictus (Roxb.) Nees (Bamboo) plantations in the landscape of central India
}

\author{
Gone Arpana Keren ${ }^{1 *}$, Pradeep Chaudhry ${ }^{1}$, Atul Sharma ${ }^{2}$, Sudeep Singh ${ }^{2}$ \\ 'Indian Institute of Forest Management, Nehru Nagar, Bhopal, India-462003 \\ ${ }^{2}$ Madhya Pradesh Rajya Van Vikas Nigam Limited, Bhopal, India-462003 \\ "e-mail: agone20@iifm.ac.in
}

Received: 12 May 2019 / Accepted: 22 September 2019

\begin{abstract}
The Kyoto Protocol addresses the issues related to global warming and it is the responsibility of the signatory countries to protect the sinks and reservoirs of greenhouse gases, to increase forest plantations and to promote sustainable forest management. India is also one of the signatories of the Kyoto Protocol, which is why various forest plantations have been established in the country. The present study compares the carbon sequestration potential of three-year-old Tectona grandis (teak) and Dendrocalamus strictus (bamboo) plantations in the state of Madhya Pradesh of India. It is concluded that $D$ strictus sequesters more carbon than $T$. grandis and both species are suited for plantations in tropical areas of India.
\end{abstract}

Key words: biomass carbon, corporate social responsibility, deforestation, climate change.

\section{Introduction}

Forest plantations have been considered as a very effective measure to sequester atmospheric carbon and mitigate future climate change (Winjum \& Schroeder, 1997). Presently about $4 \%$ of world's forests are plantations, established to provide a variety of direct and indirect benefits to human society (Pawson et al., 2013). Globally planted forest area increased by over 105 million ha since 1990. The average annual rate of increase between 1990 and 2000 was 3.6 million ha. The rate peaked at 5.9 million ha per year for the period 2000 to 2005 and slowed to 3.3 million ha per year between 2010 and 2015, as planting decreased in East Asia, Europe, North America, and south and southeast Asia (Global Forest Resources Assessment, 2015). Forest plantations area at global level need to be increased to much larger extent as a strategy to tackle global warming and climate change issue. Such plantations are being raised in India also under various projects and schemes. Organizations and industries, both in public and private sector, responsible for greenhouse gas emissions due to their operations are planting trees as part of their corporate social responsibility (CSR). National thermal power corporation (NTPC) is one such public sector organizations of India, responsible for generating electricity through coal based thermal power plants throughout the country and also raising forest plantations around power plants and in forest areas to help mitigate the atmospheric carbon dioxide increase during last one hundred years. In this context, NTPC signed a memorandum of understanding (MoU) in 2016 with Madhya Pradesh State Forest Development Corporation Ltd., a state government enterprise, 
to raise forest plantations of local species as part of their CSR and to tackle global atmospheric carbon increase issue.

This paper presents the details of the baseline study on carbon dioxide sequestration potential of young plantations of Tectona grandis and Dendrocalamus strictus conducted by the first author as part of her summer internship work at IIFM Bhopal during April 2019 to June 2019 period. The purpose of the work was to assist the Madhya Pradesh State Forest Development Corporation Ltd. in estimating the carbon sequestration potential of two prominent tropical species of the region. These plantations were raised by the state forest development corporation in forest areas of four forest divisions of the Madhya Pradesh state namely Barghat, Sidhi, Sehore and Khandwa between period 2016 to 2018 .

\section{Materials and method}

A survey was conducted in two forest divisions namely Barghat and Sehore (Fig. 1). The details of plantations raised in these forest divisions are given in Table 1. Major forest types of these area are tropical dry deciduous forests.

All sample plots were selected randomly. Number of sample plots to be laid was calculated using the formula:
Number of sample plots

$$
n=\frac{N^{2} \times s^{2}}{\frac{\mathbb{(}\left(N \rrbracket^{2} \times E^{2}\right)}{t^{2}}+N \times s^{2}}
$$

where:

$n=$ number of sample plots,

$N=$ area of the plot in hectares,

$s=$ standard deviation of the sample plots,

$E=$ allowable error (calculated by multiplying the mean biomass carbon stock by the desired precision),

$t=$ the sample statistic from the $\mathrm{t}$ distribution.

When estimated by above equation, the minimum number of sample plots was estimated as 3 . Therefore, number of sample plots laid was taken on higher side slightly as 4 in each plantation in order to obtain accurate results. The sample plot was of size 0.1 ha with dimensions $31.62 \mathrm{~m}$ x $31.62 \mathrm{~m}$. Non-destructive sampling method was used to collect the data required to calculate the total biomass carbon of the plantation. Diameter at breast height (DBH) and height of the all trees in the $T$. grandis plantation were recorded. In the D. strictus plantations, height and culm density of all the clumps in the plantation were recorded. Girth at breast height was measured with a diameter tape (later DBH was obtained from the girth) and height was measured with the help of Haga-altimeter.

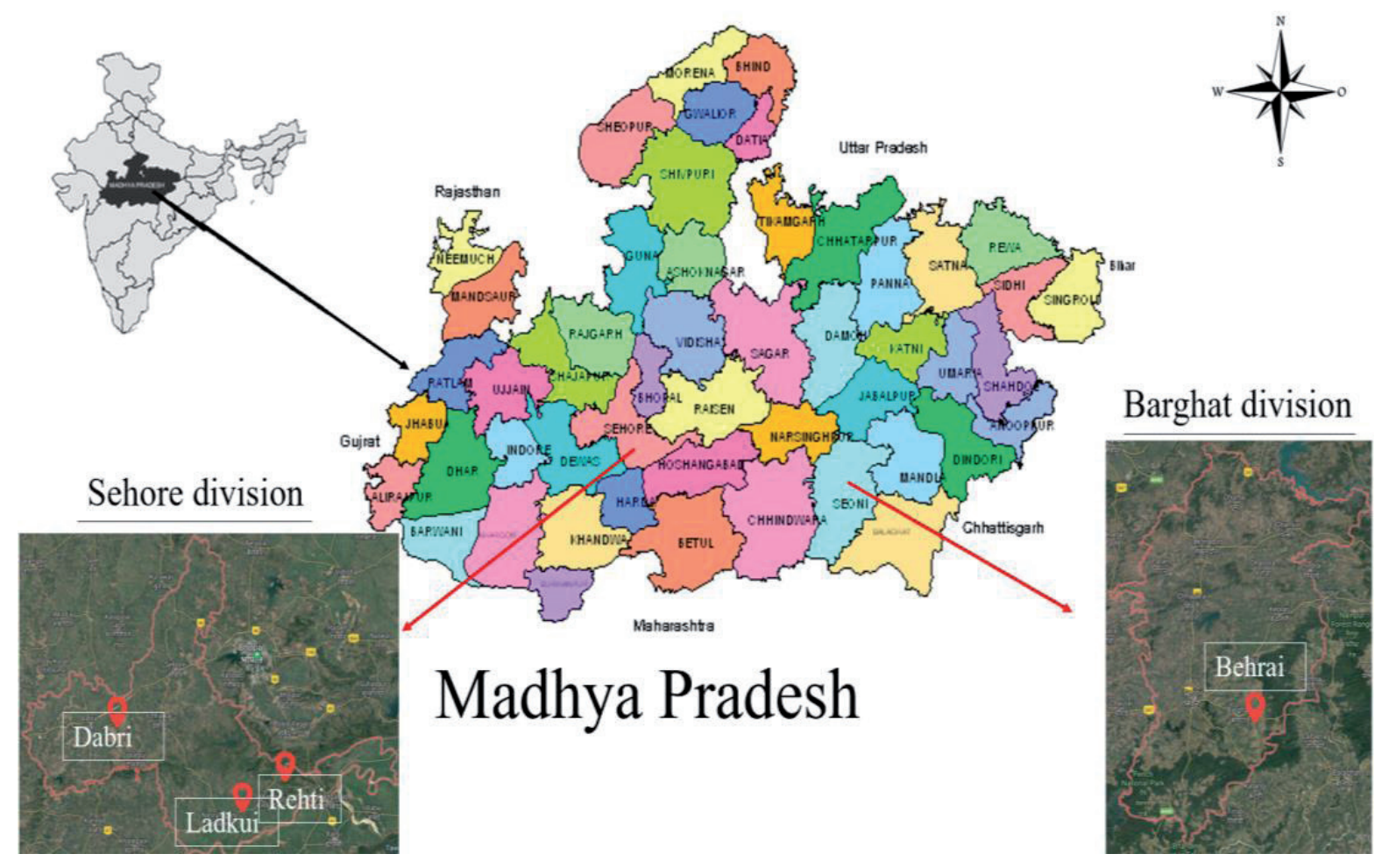

Figure 1. Locational details of plantations in Madhya Pradesh state 
Table 1. Number of teak and bamboo plantations studied

\begin{tabular}{|c|c|}
\hline Forest divisions & 3 years \\
\hline Barghat & 策鹤 \\
\hline Sehore & 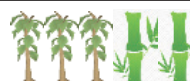 \\
\hline
\end{tabular}

Following local allometric equations developed by Jha (2015) were used to calculate the biomass carbon of 3-year old $T$. grandis plantations.

Total biomass of $T$. grandis $\mathrm{Y}=1.95+0.028 \times$ $\times D B H^{2} \times H$

where $Y$ is the total biomass in $\mathrm{kg}, D B H(\mathrm{~cm})$ and $H(\mathrm{~m})$

Local allometric equation developed by (Singh et al., 2006) was used to calculate the biomass carbon of 3-year old D. strictus plantations.

Total biomass of $D$. strictus $H=(67.23961+$ $+0.071139 \times H) / 50$

where $Y=$ total biomass, $\mathrm{kg} / \mathrm{culm}, H=$ height, $\mathrm{m}$.

Biomass carbon stock was obtained by multiplying the total biomass with IPCC-GPG default value 0.5 (IPCC, 2003).

Total biomass carbon $\left(\mathrm{t} \mathrm{ha}^{-1}\right)=T B \times 0.5$.

\section{About Tectona grandis}

Local name of the species in central India is Sagon. It is a tropical hardwood species and belongs to family of Lamiaceae. It is native to south and south east Asia, mainly India, Malaysia, Indonesia, Thailand, and Burma, but is naturalized and cultivated in many countries. Africa and Caribbean Burma accounts for about one-third of the world's total $T$. grandis production. It is a deciduous tree that is dominant in mixed hardwood forests and it has small, fragrant white flowers and papery leaves that are often hairy on the lower surface. T. grandis timber is mainly valued for its durability and water resistance and is used for boat building, veneer, furniture, exterior construction, carving, turnings, and other small wood projects, hence it is the most valued and expensive timber crop of India. $T$. grandis plantations have very good carbon sequestration potential and help in the absorption of atmospheric carbon dioxide.

\section{About Dendrocalamus strictus}

Bamboos are a unique group of monocotyledonous, perennial, fast growing, arborescent plants belonging to the tribe Bambuseae of the family Poaceae. They occur in the tropical and subtropical evergreen and deciduous forest formations of Asia-Pacific. China, India, and Myanmar have 19.8 million hectares of bamboo which is about 80 percent of world bamboo forests; of this India's share is 45 percent. The principal bamboo species are Bambusa bambos and Dendrocalamus strictus with an overall annual production of 5 million tons. Important uses of bamboo include paper and pulp, food, feed, house construction, scaffolding, making articles of everyday use, controlling soil erosion and facilitating on-site nutrient conservation (Lobovikov et al. (FAO UN), 2007). Bamboo has many advantages over tree species in terms of sustainability and carbon fixing capacity. Bamboo is one of the fastest growing and most productive plants on the planet. The fastest growing species among the bamboos grows up to $1.2 \mathrm{~m}$ a day. Bamboos are excellent carbon sinks and may form part of clean development mechanism projects in the near future (Kumar \& Kunhamu, 2011).

Due to fast growth, it has the potential to store carbon more efficiently which makes it a viable option for mitigating climate change (Kaushik et al., 2015). D. strictus is a better option compared to a few tropical and temperate plantation species as regards the magnitude of carbon storage in given time (Singh et al., 2006).

According to a study conducted by Singh and Singh (1999), net accumulation of culms during 3rd and 4th year was found as 3,999 $\mathrm{ha}^{-1}$ and between 4 th and 5 th year $10,854 \mathrm{ha}^{-1}$. Total biomass was $46.9 \mathrm{t} \mathrm{ha}^{-1}$ in the 3 -year old plantation to $74.7 \mathrm{t} \mathrm{ha}^{-1}$ in the 5-year old plantation with $35 \%$ occurring belowground. The clump density was 2,500 clumps per ha.

A study conducted by Kaushal et al. (2016) revealed that the total biomass carbon stock in D. strictus was 8.39 and $49.08 \mathrm{t} \mathrm{ha}^{-1}$ respectively in young (6-year old) and mature plantation (20-year old). The clump density was 500 
clumps per ha. Carbon content in different parts revealed that it was higher in culm $(48.66 \%)$ followed by branch $(48.09 \%)$ and leaf $(44.68 \%)$.

\section{Results}

\subsection{Barghat site}

There were two 3-year old plantations of both the species, teak and bamboo in Behrai range of Barghat forest division
(Fig. 2). The plantations were planted in the year 2016. The T. grandis plantations were raised by root-shoot planting technique at a spacing of $2 \mathrm{~m} \times 2 \mathrm{~m}$ whereas, the $D$. strictus plantations were raised by polypots in nursery and then planted in field at spacing $4 \mathrm{~m} \mathrm{x} 4 \mathrm{~m}$.

Area of $T$. grandis and D. strictus plantation was 5 and 20 ha respectively in compartment 118 of Behrai range. A $t$-test was used to compare the mean biomass carbon stock between $D$. strictus and $T$. grandis plantations. At $95 \%$ confidence interval, $\alpha$-value -0.05 and the null hypothesis was assumed that there was no significant differ-

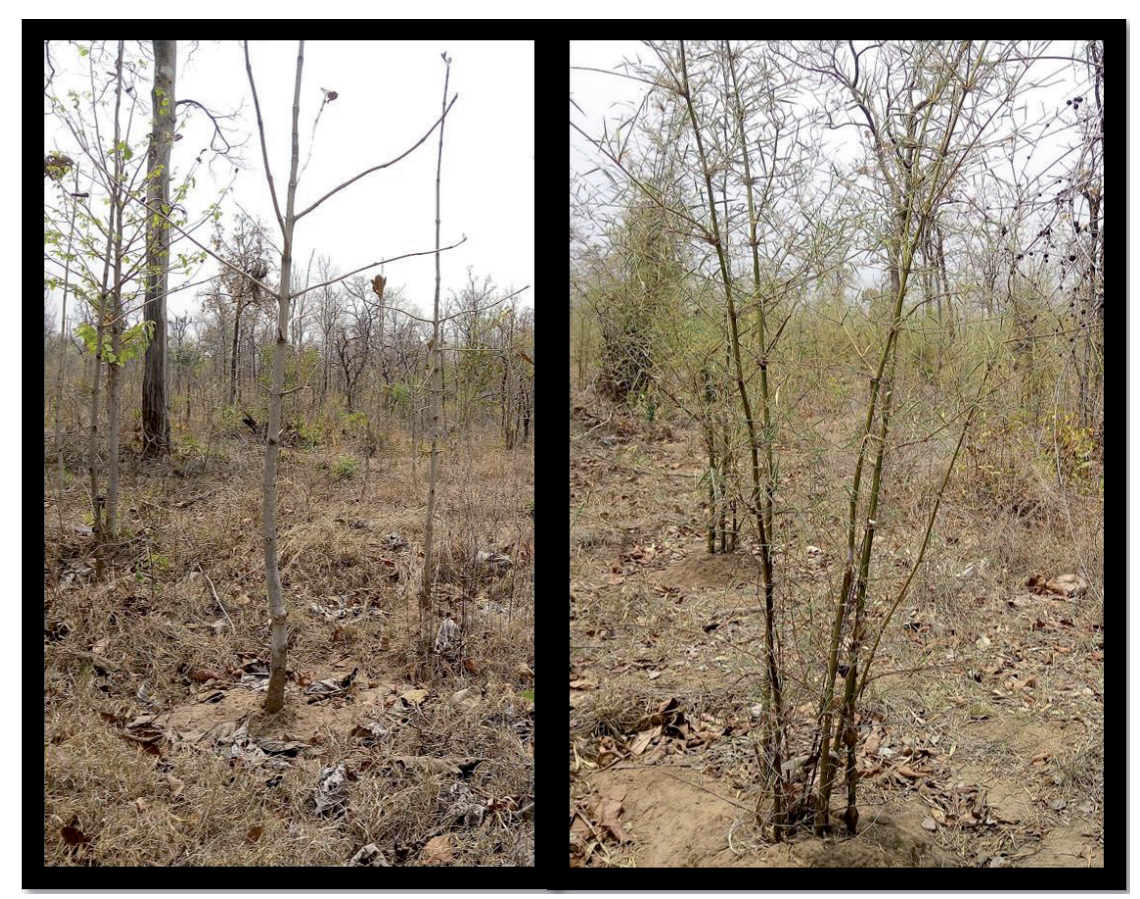

Figure 2. Three-year old Teak and Bamboo plantation in Behrai range of Barghat forest division

Table 2. Comparing mean biomass carbon stock between D. strictus and T. grandis plantations in compartment 118 of Behrai range of Barghat forest division

\begin{tabular}{|c|c|c|c|}
\hline Species & Mean $\left(\mathbf{t ~ h a}^{-\mathbf{1}}\right)$ & $\boldsymbol{t}$-Value & $\boldsymbol{p}$-Value \\
\hline D. strictus & $5.26 \pm 0.02$ & 127.36 & 0.000 \\
\hline T. grandis & $2.34 \pm 0.20$ & & \\
\hline
\end{tabular}

Table 3. Comparing mean biomass carbon stock between D. strictus and T. grandis plantations in compartment 286 of Behrai range of Barghat forest division

\begin{tabular}{|c|c|c|c|}
\hline Species & Mean $\left(\mathbf{t ~ h a}^{-\mathbf{1}}\right)$ & $\boldsymbol{t}$-Value & $\boldsymbol{p}$-Value \\
\hline D. strictus & $5.19 \pm 0.01$ & 679.5 & 0.000 \\
\hline T. grandis & $2.18 \pm 0.06$ & & \\
\hline
\end{tabular}


ence between the mean biomass carbon stock of $D$. strictus and T. grandis plantations. Null hypothesis was rejected as $\mathrm{p}$-value was less than $\alpha$-value and mean biomass carbon sequestration appeared to be significantly different at $5.26 \pm 0.02$ and $2.34 \pm 0.20 \mathrm{t} \mathrm{ha}-1$ for D. strictus and $T$. grandis, respectively (Table 2 ). The ratio of $D$. strictus to $T$. grandis is 2.24 , indicating that $D$. strictus plantation has a higher carbon accumulation capability than T. grandis.

Area of $T$. grandis and D. strictus plantation was 5 and 20 ha respectively in compartment 286 of Behrai range. Mean biomass carbon sequestration was significantly different at $5.19 \pm 0.01$ and $2.18 \pm 0.06 \mathrm{tha}^{-1}$ for D. strictus and $T$. grandis, respectively (Table 3 ). The ratio of $D$. strictus to $T$. grandis biomass is 2.37 , indicating that D. strictus plantation has a higher carbon accumulation capability than $T$. grandis.

\subsection{Sehore site}

There was one 3-year old plantation of both the species in three forest ranges namely Rehti, Ladkui, and Dabri in Sehore forest division. The plantations in Sehore were planted in the year 2016. The T. grandis plantations were raised by root-shoot planting technique at a spacing of $2 \mathrm{~m} \times 2 \mathrm{~m}$. Whereas, the D. strictus plantations were raised by polypots in nursery and planted at spacing of $4 \mathrm{~m} \mathrm{x} 4 \mathrm{~m}$ in the field. Area of T. grandis and D. strictus plantation was 3.13 and 12.49 ha respectively in compartment 597 of Rehti range.

Mean biomass carbon sequestration was significantly different at $1.67 \pm 0.01 \mathrm{t} \mathrm{ha}^{-1}$ and $2.0 \pm 0.01 \mathrm{t} \mathrm{ha}^{-1}$ for D. strictus and $T$. grandis (Table 2).

This was the only compartment where $T$. grandis had more biomass carbon stock than $D$. strictus (Table 4). The reason being different treatment for both the plantations.
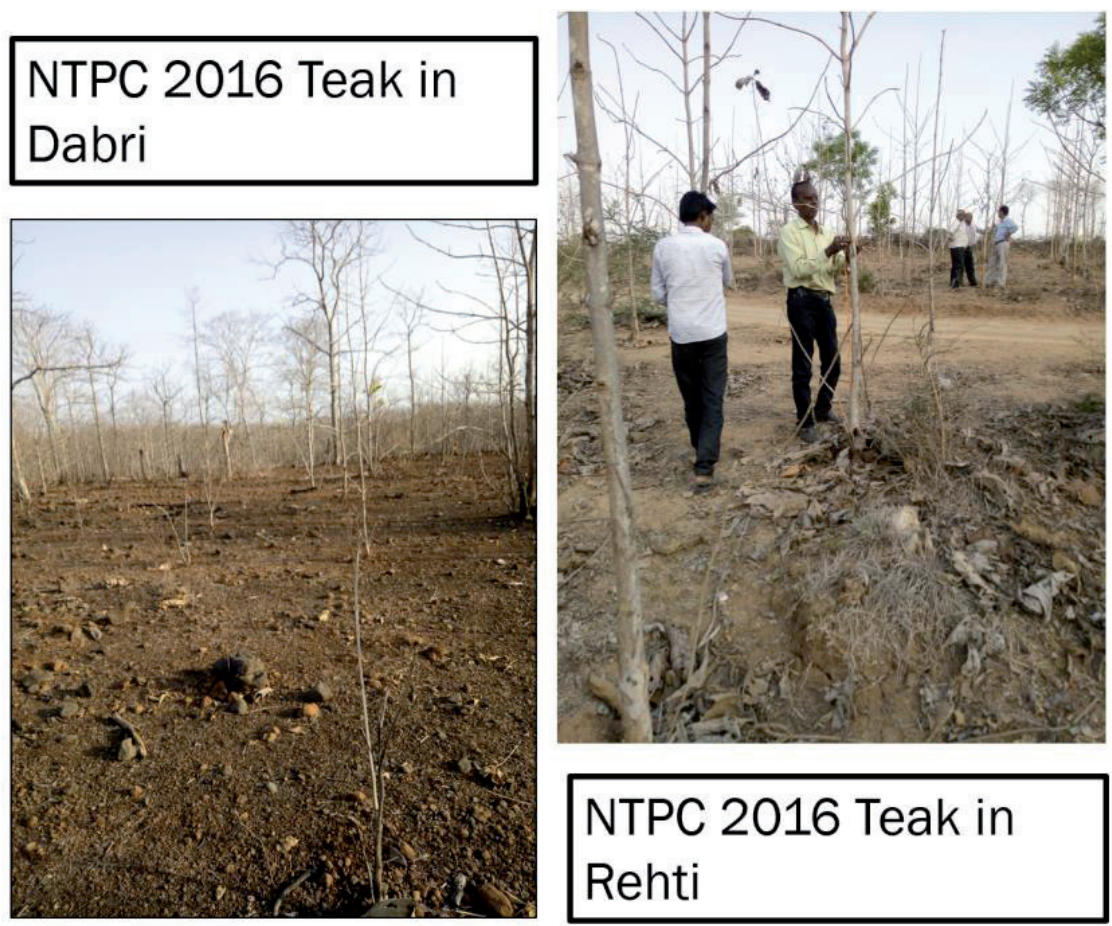
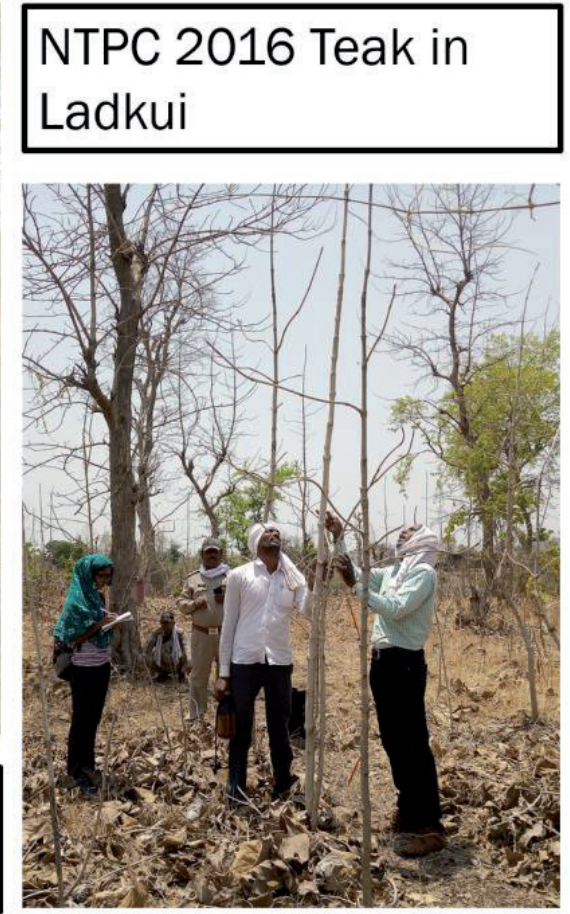

Figure 3. Three-year old T. grandis plantations in Sehore forest division

Table 4. Comparing mean biomass carbon stock between D. strictus and T. grandis plantations in compartment 597 of Rehti range of Sehore forest division

\begin{tabular}{|c|c|c|c|}
\hline Species & Mean $\left(\mathbf{t ~ h a}^{-\mathbf{1}}\right)$ & $\boldsymbol{t}$-Value & $\boldsymbol{p}$-Value \\
\hline D. strictus & $1.67 \pm 0.01$ & -49.75 & 0.000 \\
\hline T. grandis & $2.0 \pm 0.01$ & & \\
\hline
\end{tabular}


There were biotic factors, affecting the plantation, like rabbits and termites eating up the D. strictus shoots. Hence the results of the plantation in this range are not considered for decision making as far as the comparison between T. grandis and D. strictus was concerned.

Area of T. grandis and D. strictus plantation was 6.84 and 27.5 ha respectively in compartment 424 of Ladkui range. Mean biomass carbon sequestration was significantly different at $5.02 \pm 0.01 \mathrm{t} \mathrm{ha}^{-1}$ and $2.60 \pm 0.001 \mathrm{t} \mathrm{ha}^{-1}$ for
D. strictus and T. grandis, (Table 5). The ratio of D. strictus to $T$. grandis is 1.92 , indicating that $D$. strictus plantation has a higher carbon accumulation capability than $T$. grandis.

Area of T. grandis and D. strictus plantation was 10 and 40 ha respectively in compartment 260 of Dabri range. Mean above ground carbon sequestration appeared to be significantly different at $3.90 \pm 0.01$ and $1.77 \pm 0.001 \mathrm{t} \mathrm{ha}^{-1}$ for D. strictus and T. grandis, respectively (Table 6). The
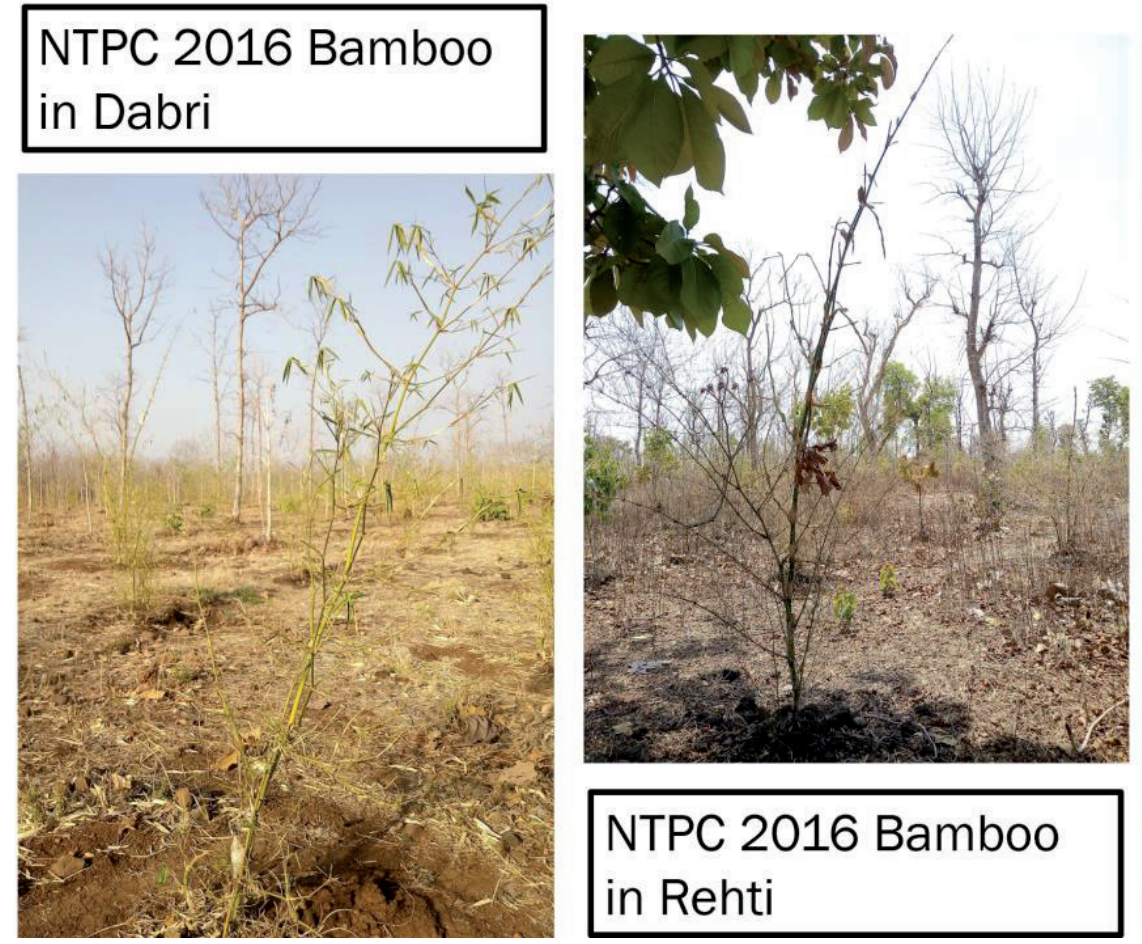

Figure 4. Three-year old D. strictus plantations in Sehore forest division

Table 5. Comparing mean biomass carbon stock between D. strictus and T. grandis plantations in compartment 424 of Ladkui range of Sehore forest division

\begin{tabular}{|c|c|c|c|}
\hline Species & Mean $\left(\mathbf{t ~ h a}^{-\mathbf{1}}\right)$ & t-Value & p-Value \\
\hline D. strictus & $5.02 \pm 0.01$ & 843.9 & 0.000 \\
\hline T. grandis & $2.60 \pm 0.001$ & & \\
\hline
\end{tabular}

Table 6: Comparing mean biomass carbon stock between D. strictus and T. grandis plantations in compartment 260 of Dabri range of Sehore forest division

\begin{tabular}{|c|c|c|c|}
\hline Species & Mean $\left(\mathbf{t} \mathbf{h a}^{-\mathbf{1}}\right)$ & $\boldsymbol{t}$-Value & $\boldsymbol{p}$-Value \\
\hline D. strictus & $3.90 \pm 0.01$ & 879.09 & 0.000 \\
\hline T. grandis & $1.77 \pm 0.001$ & & \\
\hline
\end{tabular}


ratio of $D$. strictus to $T$. grandis was 2.19 , indicating that D. strictus plantation has a higher carbon accumulation capability than $T$. grandis.

\section{Discussion}

Forests covered an area of $869,012 \mathrm{~km}^{2}$ in 1930 in India which came down to $625,565 \mathrm{~km}^{2}$ in 2013 , a net loss of $243,447 \mathrm{~km}^{2}(28 \%)$ in eight decades. The highest annual average forest loss was $4795 \mathrm{~km}^{2}$, observed during 1930-1975, $1476 \mathrm{~km}^{2}$ during 1975-1985, $767 \mathrm{~km}^{2}$ during 1985-1995, $356 \mathrm{~km}^{2}$ during 1995-2005 and $209 \mathrm{~km}^{2}$ during 2005-2013. Between 1930 and 1975, forest experienced large scale deforestation at gross annual rate of $0.77 \%$, probable reason being land needed for agricultural expansion, which declined to $0.29 \%$ and $0.14 \%$ for the 1975 1985 and 1985-1995 periods respectively (Reddy et al., 2016). During last period i.e. 1975-1985, Forest Conservation Act, 1980 came into force, hence deforestation rate was curtailed According to another estimate of a FAO study, annual deforestation rate was $0.6 \%$ between 1981 and 1990 (Bruinsma, 2017), while another study suggests that India's total forest area declined by only $0.04 \%$ between 1982 and 1990 (Ravindranath, 1994).

Disparity in the estimates of deforestation might result from differences in methodology, in definition and classification of forest and land use types, and unavailability or inaccessibility of accurate maps (Menon \& Bawa, 1998). However, it is a general accepted fact that major deforestation has mostly occurred due to conversion of forests to agriculture mainly before 1980 i.e. before enactment of Forest Conservation Act, 1980 (Kumar, 2015). The construction of reservoirs contributed to 4 to $5 \%$ of forest loss (Behera et al., 2018). Moreover, the tropical forests have experienced large scale deforestation followed by subtropical forests in the country (Barlow, 2016). All above destruction of forests became a major cause of accumulation of large amount of $\mathrm{CO}_{2}$ in the atmosphere (Landry, 2016). In fact, deforestation is considered as largest anthropogenic source of $\mathrm{CO}_{2}$ to atmosphere after fossil fuel combustion (van der Werf et al., 2009). Hence raising of artificial plantations of suitable native species in degraded forest areas is the need of the hour to fight the problem of climate change and global warming. Indian government is very serious on this aspect and lot of emphasis has been put on raising forest plantations in the country as United Nations Framework Convention on Climate Change (UNFCCC) has recognized the importance of plantation forestry as a greenhouse gas mitigation option, and enhance terrestrial biomass carbon stocks (Updegraff et al., 2004).

From the $t$-tests conducted in the two forest divisions (Barghat and Sihore) plantations to compare mean biomass carbon stock between D. strictus and T. grandis in our study, it can be concluded that D. strictus sequesters more carbon than $T$. grandis as in all compartments $D$. strictus plantation had more biomass carbon stock than $T$. grandis except in compartment 597 of Rehti range of Sehore division. This was due to poor maintenance of D. strictus plantations and the species was planted in degraded soil. Other similar studies also have proved that $D$. strictus sequesters more than T. grandis (Singh et al., 2006; Melkania, 2009).

Results of carbon sequestration potential of $T$ grandis as estimated by researchers in other studies mentioned below are comparable to results found in our study. For example, Jana et al. (2009) studied above ground biomass carbon potential of four young species (6-year old). The total above-ground biomass carbon stock per hectare as estimated for Shorea robusta, Albizzia lebbeck, Tectona grandis and Artocarpus integrifolia were 5.22, 6.26, 7.97 and $7.28 \mathrm{t} \mathrm{ha}^{-1}$, respectively in forest stands of West Medinipur district of W Bengal. The annual CSR (carbon sequestration rate) from ambient air were estimated at $8.97 \mathrm{t} \mathrm{ha}^{-1}$ by Shorea robusta, $11.97 \mathrm{t} \mathrm{ha}^{-1}$ by Albizzia lebbeck, $2.07 \mathrm{t} \mathrm{ha}^{-1}$ by Tectona grandis and $3.33 \mathrm{t} \mathrm{ha}^{-1}$ by Artocarpus integrifolia.

Raizada et al. (2003) estimated rate of carbon flux in selected planted forests in India. They studied ten species e.g. Eucalyptus spp., Tectona grandis, Acacia auriculiformis, Pinus roxburghii, Dalbergia sisoo, Shorea robusta, Gmelina arborea, Casuarina equisetifolia, Populus deltoids and Bombax ceiba. Carbon flux (Mt C yr. ${ }^{-1} \mathrm{ha}^{-1}$ ) was found maximum for Shorea robusta (5.07 $\mathrm{Mt} \mathrm{C} \mathrm{yr.}^{-1}$ $\left.\mathrm{ha}^{-1}\right)$ and minimum for Bombax ceiba $\left(0.58 \mathrm{Mt} \mathrm{C} \mathrm{yr.}^{-1} \mathrm{ha}^{-1}\right)$. For $T$. grandis this value was $1.62 \mathrm{Mt} \mathrm{C} \mathrm{yr.}^{-1} \mathrm{ha}^{-1}$.

According to Kaul et al. (2010), the net annual carbon sequestration rates were found higher in fast growing short rotation poplar (8 $\mathrm{Mg} \mathrm{C}^{-1} \mathrm{hr}^{-1}$ ) and Eucalyptus (6 Mg $\mathrm{C} \mathrm{ha}^{-1} \mathrm{yr}^{-1}$ ) plantations in comparison to moderate growing teak forests $\left(2 \mathrm{Mg} \mathrm{C} \mathrm{ha}^{-1} \mathrm{yr}^{-1}\right)$ and slow growing long rotation sal forests $\left(1 \mathrm{Mg} \mathrm{C} \mathrm{ha}^{-1} \mathrm{yr}^{-1}\right)$. Razada et al. (2003) was also of the view that short rotation planted forests having regular leaf shading patterns possess more capacity for carbon sequestration in litter. When we talk about carbon sequestration potential of matured forests in central region of India, teak dominated forests were found on higher side as $33-53 \mathrm{Mg} \mathrm{ha}^{-1}$ (14.7-23.64 tons acre $\left.{ }^{-1}\right)$ in comparison to mixed non teak forests (as 25-54 $\mathrm{Mg} \mathrm{ha}^{-1}$ or 11.15-24.08 tons acre ${ }^{-1}$ ) and dry mixed non teak forest (as 13-42 $\mathrm{Mg}$ $\mathrm{ha}^{-1}$ or 5.8-18.73 tons acre $^{-1}$ ) (Salunkhe \& Khare, 2016).

\section{Conclusion}

Based on our study, it is strongly recommended to plant $D$ strictus and $T$ grandis on large scale in degraded forest areas of tropical region of country. There is a big opportunity if Madhya Pradesh Forest Development Corpora- 
tion Limited can merge people who live in villages where the plantations are carried out, with Sericulture which requires Terminalia arjuna tree for Tasar silkworm rearing. These trees can be planted and the villagers can participate in Sericulture activities. By that way, they can earn by sericulture and simultaneously the trees would sequestrate carbon also.

After the preliminary field visit, it was found prudent to change the methodology to suit the constraints of time and team size. In this context, high-resolution remote sensing data can be used along with GIS to identify and demarcate the boundaries of the study area as well as for creating sampling strata based on vegetation and biomass densities.

Madhya Pradesh Forest Development Corporation Limited may like to consider having a Custom-made and integrated GIS application developed for more efficient management and real-time monitoring of the plantations. The corporation can also be benefited by selling carbon credits on Multi Commodity exchange (MCX), which started future trading on 4th January 2008 after Government of India recognized carbon credit as commodities.

\section{Acknowledgement}

The first author is thankful to all the officers and field staff of Madhya Pradesh Rajya Van Vikas Nigam Ltd., for their financial and logistics support that was provided throughout the study.

\section{References}

Barlow J.L., 2016, Anthropogenic disturbance in tropical forests can double biodiversity loss from deforestation. Nature 535(7610): 144-147.

Behera M D., Tripathi P., Das P., Srivastava S.K., Roy P.S., Joshi C., Behera P.R., Deka J., Kumar P., Khan M.L. \& Tripathi, O.P., 2018, Remote sensing based deforestation analysis in Mahanadi and Brahmaputra river basin in India since 1985. Journal of Environmental Management 206: 1192-1203. (doi: 10.1016/j.jenvman.2017.10.015. Epub 2017 Nov 15).

Bruinsma J., 2017, World Agriculture: Towards 2015/2030: An FAO study. Routledge, London.

Global Forest Resources Assessment, 2015, How are the world's forests changing? FAO, Rome. (http://www. fao.org/3/a-i4793e.pdf).

IPCC, 2003, Intergovernmental Panel on Climate Change, Good Practice Guidance for Land Use, Land-Use Change and Forestry, edited by J. Penman, M. Gytarsky, T. Hiraishi, T. Krug, D. Kruger, R. Pipatti, L. Buendia, K. Miwa, T. Ngara, K. Tanabe, F. Wagner. Institute for
Global Environmental Strategies (IGES), Kamiyamaguchi, Japan. (http://www.ipcc-nggip.iges.or.jp).

Jana B.K., Biswas S., Majumder M. \& Roy P.K., 2009, Carbon Sequestration Rate and Aboveground Biomass Carbon Potential of Four Young Species. Journal of Ecology and Natural Environment 1(2): 15-24.

Jha K.K., 2015, Carbon storage and sequestration rate assessment and allometric model development in young teak plantations of tropical moist deciduous forest, India. Journal of Forestry Research 26(3): 589-604.

Kaul M, Mohren G.M.J. \& Dadhwal V.K., 2010, Carbon storage and sequestration potential of selected tree species in India. Mitigation and Adaptation Strategies for Global Change 15(5): 489-510.

Kaushal R., Subbulakshmi V., Tomar J.M.S., Alam N.M., Jayaprakash J, Mehta H. \& Chaturvedi O.P., 2016, Predictive models for biomass and biomass carbon stock estimation in male bamboo (Dendrocalamus strictus L.) in Doon valley, India. Acta Ecologica Sinica 36(6): 469-476.

Kaushik S., Singh Y.P., Kumar D., Thapliyal M. \& Barthwal S., 2015, Bamboos in India. ENVIS Centre on Forestry. National Forest Library and Information Centre. FRI, Dehradun, India.

Kumar B.M. \& Kunhamu T.K., 2011, Quarter Century of Agroforestry Research in Kerala: A Compendium of Research Publications. Kerala Agricultural University, Thrissur, Kerala, India.

Kumar K.S., 2015, Decentralisation and democratic forest reforms in India: Moving to a rights-based approach. Forest Policy and Economics 51: 1-8.

Landry J.S., 2016, Non-deforestation fire vs. fossil fuel combustion: the source of $\mathrm{CO}_{2}$ emissions affects the global carbon cycle and climate responses. Biogeosciences (BG) 13: 2137-2149.

Lobovikov M., Paudel S., Piazza M., Ren H. \& Wu J., 2007, World Bamboo Resources: a thematic study prepared in the framework of the Global Forest Resources Assessment 2005. Food and Agriculture Organization of United Nations, Rome. (http://www.fao.org/3/aa1243e.pdf).

Melkania N.P., 2009, Carbon sequestration potential in Indian natural and planted forests. Indian Forester 135: 380-392.

Menon S. \& Bawa K.S., 1998, Deforestation in the tropics: reconciling disparities in estimates for India. Ambio 27(7): 576-577.

Pawson S., Brin A., Brockerhoff E., Lamb D., Payn T., Paquette A. \& Parrotta J., 2013, Plantation forests, climate change and biodiversity. Biodiversity \& Conservation 22(5): 1203-1227.

Raizada A., Parandiyal A.K. \& Ghosh B.N., 2003, Estimation of carbon flux through litter fall in forest plantation of India. Indian Forester 129(7): 881-894. 
Ravindranath N.H., 1994, Indian forest conservation and tropical deforestation. Ambio 23(8): 521-523.

Reddy S.C., Jha C.S., Dadhwal V.K. \& Diwakar P.G., 2016, Quantification and monitoring of deforestation in India over eight decades. Biodiversity \& Conservation 25(1): 93-116.

Salunkhe O. \& Khare P.K., 2016, Aboveground biomass and carbon biomass stock of tropical deciduous forest ecosystems of Madhya Pradesh, India. International Journal of Ecology and Environmental Sciences 42(S): 75-81.

Singh N.A. \& Singh J.S., 1999, Biomass, net primary production and impact of bamboo plantation on soil redevelopment in a dry tropical region. Forest Ecology and Management: 119(1-3): 195-207.

Singh P., Dubey P. \& Jha K.K., 2006, Biomass production and carbon storage at harvest age in superior Dendro- calamus strictus Nees. Plantation in dry deciduous forest region of India. Indian Journal of Forestry 29(4): 353-360.

Updegraff K., Baughman M.J. \& Taff S.J., 2004, Environmental benefits of cropland conversion to hybrids poplar: Economic and policy considerations. Biomass and Bioenergy 27: 411-428.

van der Werf G.R., Morton D.C., DeFries R.S., Olivier J.G.J., Kasibhatla P.S., Jackson R.B., Collatz G.J. \& Randerson J.T., 2009, $\mathrm{CO}_{2}$ Emissions from Forest Loss. Nature Geoscience 2: 737-738.

Winjum J.K. \& Schroeder P.E., 1997, Forest plantations of the world: their extent, ecological attributes and carbon storage. Agricultural and Forest Meteorology 84: 153-167. 